\title{
Rootstock Affect Ripening and Other Qualities of 'Delicious' Apples
}

\author{
Wesley R. Autio \\ Department of Plant and Soil Sciences, University of Massachusetts, Amherst, MA 01003 \\ Additional index words. Malus domestics, mineral composition, storage, fruit maturation, fruit quality, fruit size, crop \\ load \\ Abstract. The effects of rootstock on 'Delicious' (Malus domestics Borkh.) apple ripening, quality, size, mineral \\ composition, and storability were studied over 4 years. Removal of the effects of crop load by analysis of covariance \\ suggested that M.27 EMLA advanced fruit ripening and that M.7 EMLA delayed fruit ripening. Ott.3, M.9, MAC \\ 9, OAR 1, M.9 EMLA, and M.26 EMLA either were inconsistent in their effects on ripening or consistently-resulted \\ in an intermediate time of ripening. Fruit size consistently was largest from trees on M.9 EMLA and smallest from \\ trees on OAR 1. Fruit from trees on MAC 9 generally had relatively high Ca contents, and fruit from trees on OAR \\ 1 had relatively low Ca concentrations. The effects of rootstock on storability appeared to be related to their effects \\ on maturity arid Ca levels.
}

The effects of rootstock on apple fruit characteristics have been assessed by many researchers. Studies have shown that rootstock or interstock clone can affect apple ripening and quality (Drake et al., 1988; Fallahi et al., 1985a, 1985b; Larsen et al., 1986; Lord et al., 1985; Perry and Dilley, 1984; Wallace, 1930), mineral composition (Drake et al., 1988; Jackson and Blasco, 1975), and storability (Fallahi et al., 1985b; Lord et al., 1985; Wallace, 1930). No consistent pattern of these effects emerged; however, many of these studies have included only a few rootstock, are the results of only 1 or 2 years of study, or have ignored confounding factors, such as crop load, light interception, and fruit size.

The objectives of this project were to: 1) assess, over 4 years, the effects of several rootstock of varying tree size-control capacities on apple ripening, quality, and size, taking into account potential confounding influences; 2) determine the effects of the same rootstock on mineral composition of apple fruit after removing the effects of fruit size; and 3) assess rootstock effects on apple storability.

\section{Materials and Methods}

The trees were 'Starkspur Supreme Delicious' on Ott.3, M.7 EMLA, M.9 EMLA, M.26 EMLA, M.27 EMLA, M.9, MAC 9, and OAR 1. They were planted in 1980 and 1981 as part of the NC-140 Regional Project (NC-140, 1987). The experimental design was a randomized complete block with 10 replications, five each planted in 1980 and 1981. Five 1980 replications and two 1981 replications were used in all years, except in 1989 when an additional 1981 replication was included.

Four fruit were harvested from the periphery of each tree on Ott.3, M.7 EMLA, M.27 EMLA, M.9, MAC 9, and OAR 1 on 15, 20, 25, and 30 Sept. and 5 Oct. 1986; 22, 25, 28 Sept. and 1, 4, 7, and 10 Oct. 1987; 29 Sept. and 6 Oct. 1988; and 21 and 28 Sept. and 5 and 12 Oct. 1989. After harvest, a 1-ml gas sample was removed from the core cavity of each fruit and injected into a gas chromatography for ethylene determination. Time constraints prevented study of the other three rootstock.

Harvests of 10 fruit per tree were made on 29 Sept. 1986,29

Received for publication 4 June 1990. Massachusetts Agricultural Experiment Station Paper 2972. This study was supported by grants from the International Dwarf Fruit Tree Association and by Massachusetts Agricultural Experiment Projects 539 and NC-140. The cost of publishing this paper was defrayed in part by the payment of page charges. Under postal regulations, this paper therefore must be hereby marked advertisement solely to indicate this fact.
Sept. 1987, 3 Oct. 1988, and 17 Oct. 1989. Flesh firmness was measured with an Effegi penetrometer (Effegi, Alfonsine, Italy) using an 11. 1-mm head and two opposing punctures per fruit. The concentration of soluble solids (SSC) was measured with a hand refractometer. The severity of watercore was assessed by visual rating (Bramlage and Lord, 1967). Starch disappearance was measured using iodine staining and visual rating (Priest and Lougheed, 1981). A 1-cm, equatorial slice was removed from each fruit, and a 1-cm cork borer was used to remove four cores of cortex tissue from immediately below the peel of each slice. The concentrations of $\mathrm{Ca}, \mathrm{Mg}$, and $\mathrm{K}$ were measured by atomic absorption spectrophotometry (Weis et al., 1985).

On 8 Oct. 1986, 13 Oct. 1987, 7 Oct. 1988, and 17 Oct. 1989,50 fruit (or the remaining fruit on the tree) were harvested from each tree and weighed. In 1987 and 1988, these fruit were kept in refrigerated storage at OC and $95 \%$ relative humidity for 34 and 37 weeks, respectively. After the storage period, flesh firmness was determined on 10 apples as previously described, and fruit from the 1987 and 1988 harvests were kept at 20C for 11 and 10 days, respectively. After this period, the incidence of scald, senescent breakdown, bitter pit, and decay were determined.

Analysis of variance or covariance was used for all characteristics. When the interaction of year and treatment was significant, the sums of squares for the treatment and the interaction were pooled and repartitioned into treatment effects within each year. All ripening and quality attributes and fruit size were covaried with crop load. Flesh firmness and $\mathrm{Ca}$ concentration were covaried with fruit size. The percentage of fruit with storage disorders was transformed to arcsin before analysis. All means were separated with Duncan's new multiple range test $(P=$ $0.05)$.

\section{Results}

Ripening and fruit quality. For all ripening and quality characteristics, the interaction of rootstock and year was highly significant. Additionally, analysis of covariance showed that the effects of crop load and crop load within year were highly significant for all ripening and quality features; therefore, least squares means are presented that are adjusted for these two effects.

Internal ethylene data from sequential harvests each year were transformed to log and used to establish the date when the average log ethylene level was $\mathrm{O}$ (Table 1). These data allow direct comparison of the time of initiation of the ethylene climacteric. 
Table 1. Effects of rootstocks on the date of initiation of the ethylene climacteric in 'Starkspur Supreme Delicious' apple fruit. ${ }^{2, y}$

\begin{tabular}{lcccc}
\hline Rootstock & Sept. 1986 & Oct. 1987 & Sept./Oct. 1988 & Oct. 1989 \\
\hline Ott.3 & $24 \mathrm{~b}$ & $4 \mathrm{c}$ & $29 \mathrm{~b}$ & $8 \mathrm{a}$ \\
M.7 EMLA & $28 \mathrm{ab}$ & $10 \mathrm{ab}$ & $16 \mathrm{a}$ & $8 \mathrm{a}$ \\
M.27 EMLA & $23 \mathrm{~b}$ & $6 \mathrm{bc}$ & $1 \mathrm{~b}$ & $5 \mathrm{a}$ \\
M.9 & $26 \mathrm{ab}$ & $7 \mathrm{abc}$ & $2 \mathrm{~b}$ & $7 \mathrm{a}$ \\
MAC 9 & $27 \mathrm{ab}$ & $10 \mathrm{a}$ & $3 \mathrm{~b}$ & $7 \mathrm{a}$ \\
OAR 1 & $29 \mathrm{a}$ & $3 \mathrm{c}$ & $13 \mathrm{a}$ & $7 \mathrm{a}$ \\
\hline
\end{tabular}

${ }^{2}$ Data for 1986,1987 , and 1988 are means of seven observations; data for 1989 are means of eight observations.

'Mean separation within columns by Duncan's new multiple range test, $P=0.05$.

In 1986, fruit from trees on M.27 EMLA entered the ethylene climacteric first, 6 days before fruit from trees on OAR 1. In 1.987, fruit from trees on OAR 1 entered the ethylene climacteric first, 7 days before fruit from trees on M.7 EMLA or MAC 9. In 1988, the differences among rootstock in timing of the ethylene climacteric were most prominent, with 15 days separating the earliest (fruit from trees on M.27 EMLA) and the latest (fruit from trees on M.7 EMLA). In 1989, there was no significant difference among fruit from trees on the various rootstocks.

Following the ethylene climacteric likely is the most accurate was to assess ripening differences, but it is necessary to study other attributes to obtain a clear picture of ripening. The SSC values of the fruit varied with rootstock (Table 2). In 1986, fruit from trees on M.27 EMLA or M.9 had significantly higher SSC than fruit from trees on M.7 EMLA, MAC 9, or OAR 1. No difference existed in 1987. In 1988, fruit from trees on MAC 9 had significantly higher SSC than those from trees on Ott.3, M.26 EMLA, OAR 1, or M.7 EMLA. In 1989, fruit from trees on M.27 EMLA and MAC 9 had significantly higher SSC than fruit from trees on M.7 EMLA. The incidence of watercore at harvest (Table 2) roughly reflected the differences in the SSC.

Starch index values fluctuated from year to year, but, generally, fruit from trees on M.27 EMLA had relatively high values, and fruit from trees on OAR 1 or M.7 EMLA had relatively low values (Table 3 ). The higher the value, the further ripening had progressed.

Flesh firmness was covaried with fruit size, as well as crop load and crop load within year. No clear effects of rootstock on flesh firmness were evident (Table 4). Fruit size, adjusted for crop load and crop load within year, was significantly affected by rootstock. In 1986, fruit from trees on M.9 EMLA, M.7 EMLA, or M.9 were significantly larger than those from trees on M.27 EMLA or OAR 1. In 1987, fruit from trees on M.9 EMLA were significantly larger than those from trees on M.27 EMLA, M.9, MAC 9, or OAR 1. Fruit from trees on MAC 9 were significantly larger than those from trees on M.7 EMLA, M.27 EMLA, M.9, or OAR 1 in 1988. In 1989, fruit from trees on M.9 or M.9 EMLA were significantly larger than those from trees on M.7 EMLA, M.27 EMLA, or OAR 1.

Mineral composition. Rootstock significantly affected fruit mineral composition (Table 5). The interaction of year and rootstock was significant for flesh $\mathrm{Ca}$ and $\mathrm{Mg}$ but nonsignificant for K. In 1986, Ca concentration of fruit from trees on M.9 was significantly greater than that of fruit from trees on M.9 EMLA, OAR 1, M.26 EMLA, or M.27 EMLA. In 1987, the highest Ca concentration was in fruit from trees on M.27 EMLA or MAC 9. In 1988, Ca concentration in fruit from trees on OAR 1 was significantly lower than that in all others.

No differences in fruit $\mathrm{Mg}$ concentraiton existed in 1986, but in 1987 , the $\mathrm{Mg}$ concentration of fruit from trees on M.27 EMLA or MAC 9 was significantly higher than all others. In 1988, fruit from trees on M.7 EMLA or M.27 EMLA had significantly higher $\mathrm{Mg}$ concentrations than those of fruit from trees on M.9, MAC 9, M.9 EMLA, or OAR 1. No difference existed with respect to flesh $\mathrm{K}$.

Storage properties. The interaction between year and rootstock was nonsignificant for flesh firmness but was highly significant for the incidence of storage disorders. After storage, fruit from trees on M.7 EMLA were significantly firmer than those from trees on M.9, M.26 EMLA, or M.9 EMLA (Table 6). In 1987, scald was significantly more prominent on fruit from trees on MAC 9 than on fruit from trees on Ott.3, M.26 EMLA, M.7 EMLA, or OAR 1. Scald was most prominent on fruit from trees on M.27 EMLA in 1988. Senescent breakdown was most abundant in fruit from trees on OAR 1 in 1987 and on M.9 in 1988. In 1987, the most bitter pit developed on fruit from trees on M.7 EMLA, and no difference in the incidence of bitter pit existed in 1988. Decay was most prevalent in fruit from trees on OAR 1 in 1987. In 1988, fruit from trees on M.9 developed significantly more decay than fruit from trees on M.26 EMLA, M.9 EMLA, M.7 EMLA, OAR 1, or M.27 EMLA.

\section{Discussion}

One of the earliest reports on the effects of rootstock on fruit ripening was presented by Wallace (1930). In that study, apples

Table 2. Effects of rootstocks on soluble solids concentration and watercore indices of 'Starkspur Supreme Delicious' apple fruit at harvest. ${ }^{\mathbf{z}, y}$

\begin{tabular}{|c|c|c|c|c|c|c|c|c|}
\hline \multirow[b]{2}{*}{ Rootstock } & \multicolumn{4}{|c|}{ Soluble solids concn (\%) } & \multicolumn{4}{|c|}{ Watercore index } \\
\hline & 1986 & 1987 & 1988 & 1989 & 1986 & 1987 & 1988 & 1989 \\
\hline Ott. 3 & $11.6 \mathrm{ab}$ & $10.8 \mathrm{a}$ & $11.5 \mathrm{bc}$ & $12.4 \mathrm{ab}$ & $2.1 \mathrm{abc}$ & $1.3 \mathrm{a}$ & $1.5 \mathrm{ab}$ & $3.2 \mathrm{a}$ \\
\hline M.7 EMLA & $11.0 \mathrm{~b}$ & $10.7 \mathrm{a}$ & $10.1 \mathrm{~d}$ & $12.0 \mathrm{~b}$ & $1.7 \mathrm{~cd}$ & $1.2 \mathrm{a}$ & $0.9 \mathrm{~cd}$ & $3.0 \mathrm{ab}$ \\
\hline M.9 EMLA & $11.5 \mathrm{ab}$ & $10.7 \mathrm{a}$ & $11.8 \mathrm{abc}$ & -- & $2.2 \mathrm{abc}$ & $1.3 \mathrm{a}$ & $1.5 \mathrm{ab}$ & --. \\
\hline M.26 EMLA & $11.4 \mathrm{ab}$ & $10.9 \mathrm{a}$ & $11.2 \mathrm{c}$ & -- & $1.9 \mathrm{bcd}$ & $1.1 \mathrm{a}$ & $1.7 \mathrm{ab}$ & -- \\
\hline M.27 EMLA & $12.1 \mathrm{a}$ & $10.9 \mathrm{a}$ & $12.0 \mathrm{ab}$ & $12.9 \mathrm{a}$ & $2.5 \mathrm{a}$ & $1.2 \mathrm{a}$ & $1.9 \mathrm{a}$ & $2.9 \mathrm{ab}$ \\
\hline M.9 & $11.9 \mathrm{a}$ & $10.6 \mathrm{a}$ & $11.7 \mathrm{abc}$ & $12.5 \mathrm{ab}$ & $2.4 \mathrm{ab}$ & $1.2 \mathrm{a}$ & $1.2 \mathrm{bc}$ & $3.0 \mathrm{ab}$ \\
\hline MAC 9 & $11.1 \mathrm{~b}$ & $10.4 \mathrm{a}$ & $12.4 \mathrm{a}$ & $12.8 \mathrm{a}$ & $1.5 \mathrm{~d}$ & $1.1 \mathrm{a}$ & $1.7 \mathrm{a}$ & $2.6 \mathrm{~b}$ \\
\hline OAR 1 & $11.0 \mathrm{~b}$ & $11.1 \mathrm{a}$ & $10.4 \mathrm{~d}$ & $12.3 \mathrm{ab}$ & $2.0 \mathrm{abcd}$ & $1.5 \mathrm{a}$ & $0.5 \mathrm{~d}$ & $2.8 \mathrm{ab}$ \\
\hline
\end{tabular}

zData for 1986, 1987, and 1988 are means of 70 observations; data for 1989 are means of 80 observations.

'Mean separation within columns by Duncan's new multiple range test, $P=0.05$.

${ }^{x}$ Watercore index: 1 = no watercore, 5 = severe watercore. 
Table 3. Effects of rootstocks on starch index values of 'Starkspur Supreme Delicious' apple fruit at harvest. ${ }^{\mathbf{z}, \mathbf{y}, \mathbf{x}}$

\begin{tabular}{llllc}
\hline \hline Rootstock & 1986 & 1987 & 1988 & 1989 \\
\hline Ott.3 & $2.9 \mathrm{a}$ & $2.5 \mathrm{bc}$ & $3.3 \mathrm{abc}$ & $5.4 \mathrm{bc}$ \\
M.7 EMLA & $2.5 \mathrm{ab}$ & $1.9 \mathrm{de}$ & $2.2 \mathrm{~d}$ & $5.4 \mathrm{bc}$ \\
M.9 EMLA & $3.0 \mathrm{a}$ & $2.9 \mathrm{ab}$ & $3.2 \mathrm{bc}$ &.-- \\
M.26 EMLA & $2.7 \mathrm{a}$ & $2.1 \mathrm{~cd}$ & $3.0 \mathrm{c}$ & $\ldots .$. \\
M.27 EMLA & $2.9 \mathrm{a}$ & $3.1 \mathrm{a}$ & $3.8 \mathrm{a}$ & $6.0 \mathrm{a}$ \\
M.9 & $3.0 \mathrm{a}$ & $2.9 \mathrm{ab}$ & $3.1 \mathrm{bc}$ & $5.0 \mathrm{c}$ \\
MAC 9 & $2.9 \mathrm{a}$ & $2.8 \mathrm{ab}$ & $3.5 \mathrm{ab}$ & $5.7 \mathrm{ab}$ \\
OAR 1 & $2.1 \mathrm{~b}$ & $1.5 \mathrm{e}$ & $1.4 \mathrm{e}$ & $4.5 \mathrm{~d}$ \\
\hline
\end{tabular}

${ }^{\text {}}$ Starch index value: 1 = least mature; $9=$ most mature.

yData for 1986, 1987, and 1988 are means of 70 observations; data for 1989 are means of 80 observations.

'Mean separation within columns by Duncan's new multiple range test, $P=0.05$

from trees on M.9 had higher sugar contents and poorer keeping quality than fruit from trees on other rootstock. He also noted that if the fruit from trees on M.9were harvested earlier, they had keeping quality similar to fruit from trees on other rootstock. Lord et al. (1985) used fruit from limbs with similar crop load and presented data that suggested that 'Empire' fruit ripened earlier from trees on M.27 than those from trees on M.26. However, it is difficult to know if the effects of crop load can be removed on an individual-limb basis or if it is necessary to account for the crop load on the entire tree. In 1 year of a 2-year study, Fallahi et al. (1985a) found that 'Golden Delicious' fruit from trees on M.26 tended to ripen earlier than fruit from trees on MM.106, M.7, Ml, or OAR 1, and fruit from trees on OAR 1 tended to ripen later than fruit from trees on M1, MM.106, M.7, or M.26. In the other year, few, if any, differences existed among fruit from trees on the various rootstock. Other studies have shown that rootstock can affect ripening, but insufficient data exist for the effects to be useful in expanding the harvest season in orchard production, a particular interest to fruit growers in light of the loss of daminozide for preharvest abscission control.

Apple ripening is a process that can be affected by many conditions. It is difficult to study the effects of factors, such as rootstock, that have a relatively small effect on ripening. Therefore, several years of data, a relatively large number of replications, and an effort to remove some of the confounding factors are necessary to be confident of the results. In this paper, 4 years of data are presented with a major confounding variablethe effect of crop load-removed by analysis of covariance. A strong, positive relationship was seen between crop load and date of ripening, one which was similar among rootstock but varied from year to year. The effect of crop load on ripening was most prominent in 1988, the year when the planting experienced a summer drought.

An additional factor that can confuse the results when comparing trees of dramatically different vigor is the light penetration to the fruit. Data of Smock (1953) and Meir and Bramlage (1988) suggest a positive correlation between light intensity and fruit ripening. The trees used in this study were pruned to be relatively open to light penetration, and all fruit for maturity analyses were harvested from the periphery of the tree, reducing the potential of a differential light effect.

Even with crop load and light eliminated as confounding effects, the effects of rootstock on ripening were not clear. Variation existed from year to year; however, some general comments can be made by noting the treatments that were consistently in the top or bottom Duncan's multiple range test categories with respect to ethylene climacteric, SSC, watercore index, and starch index data. Fruit from trees on M.27 consistently ripened early, with the initiation of the ethylene climacteric in the earliest category each year and with the SSC, watercore index, and starch index in the highest category each year. Fruit from trees on M.7 EMLA ripened relatively late, with the initiation of the ethylene climacteric in the latest category each year and with the SSC, watercore index, and starch index values in the lowest category each year. The difference from the earliest to the latest was the most prominent ( $\approx 2$ weeks) in 1988 , suggesting that stress may play a role in the effect of rootstock on maturity. Cummins and Norton (1974) suggested that M.7 is relatively drought-tolerant, and in 1988, trees on M.7 EMLA may have experienced a relatively small degree of stress, whereas trees on M.27 EMLA, for instance, may have been more severely affected by the dry conditions, resulting in a stress-induced advancement of maturation. Other stresses, such as waterlogging, may have a similar effect on ripening for those trees that do not easily tolerate that stress.

Fruit size was dramatically affected by rootstock, even with the removal of the effects of crop load and crop load within year. Fruit from trees on OAR 1 were always the smallest. Fallahi et al. (1985a) also suggested that OAR 1 resulted in small fruit. The largest fruit generally were from trees on M.9

Table 4. Effects of rootstocks on flesh firmness and size of 'Starkspur Supreme Delicious' apple fruit at harvest. ${ }^{2}$

\begin{tabular}{|c|c|c|c|c|c|c|c|c|}
\hline \multirow[b]{2}{*}{ Rootstock } & \multicolumn{4}{|c|}{ Flesh firmness $(\mathrm{N})^{\mathrm{y}}$} & \multicolumn{4}{|c|}{ Fruit size $(\mathrm{g})^{\mathrm{x}}$} \\
\hline & 1986 & 1987 & 1988 & 1989 & 1986 & 1987 & 1988 & 1989 \\
\hline Ott.3 & $81.2 \mathrm{~b}$ & 77.9 & 79.3 & 72.2 & $180 \mathrm{ab}$ & $220 \mathrm{ab}$ & 22 & 230 \\
\hline$A$ & $2 a b$ & 77.8 & 77. & 73.0 & 19 & 00 & & \\
\hline M.9 & $81.7 \mathrm{~b}$ & $76.6 \mathrm{c}$ & $78.8 \mathrm{ab}$ & ... & $190 \mathrm{a}$ & $230 \mathrm{a}$ & $220 \mathrm{ab}$ & $240 \mathrm{a}$ \\
\hline MLA & $82.4 \mathrm{ab}$ & $77.9 \mathrm{bc}$ & $77.4 \mathrm{ab}$ & ... & $170 \mathrm{abc}$ & $210 a b c$ & $220 \mathrm{ab}$ & 230 \\
\hline M.27 EMLA & $84.4 \mathrm{a}$ & $80.2 \mathrm{ab}$ & $79.2 \mathrm{ab}$ & $72.8 \mathrm{ab}$ & $160 \mathrm{bc}$ & $200 \mathrm{bcd}$ & $200 \mathrm{~b}$ & $210 \mathrm{~b}$ \\
\hline M.9 & $82.4 \mathrm{ab}$ & $78.6 \mathrm{bc}$ & $77.9 \mathrm{ab}$ & $73.8 \mathrm{ab}$ & $190 \mathrm{a}$ & $200 \mathrm{bcd}$ & $200 \mathrm{~b}$ & $240 \mathrm{a}$ \\
\hline MAC & $81.0 \mathrm{~b}$ & $78.9 \mathrm{bc}$ & $79.8 \mathrm{a}$ & $71.6 \mathrm{~b}$ & $180 \mathrm{ab}$ & $190 \mathrm{~cd}$ & 230 a & $230 \mathrm{ab}$ \\
\hline OAR 1 & $84.2 \mathrm{a}$ & $81.4 \mathrm{a}$ & $78.2 \mathrm{ab}$ & $74.6 \mathrm{a}$ & $150 \mathrm{c}$ & $180 \mathrm{~d}$ & $150 \mathrm{c}$ & $180 \mathrm{c}$ \\
\hline
\end{tabular}

${ }^{z}$ Mean separation within columns by Duncan's new multiple range test, $P=0.05$.

y Data for 1986, 1987, and 1988 are means of 140 observations; data for 1989 are means of 160 observations.

'Data for 1986, 1987, and 1988 are means of 350 observations; data for 1989 are means of 400 observations. In some cases, the number of fruit available for size determination in each year was less than 50 per tree, thus reducing the total number of observations per mean. 
Table 5. Effects of rootstocks on mineral concentrations of 'Starkspur Supreme Delicious' apple fruit at harvest. ${ }^{z, y}$

\begin{tabular}{|c|c|c|c|c|c|c|c|}
\hline \multirow[b]{2}{*}{ Rootstock } & \multicolumn{3}{|c|}{ Flesh Ca $\left(\mathrm{mg} \cdot \mathrm{kg}^{-1}\right)$} & \multicolumn{3}{|c|}{ Flesh $\mathrm{Mg}\left(\mathrm{mg} \cdot \mathrm{kg}^{-1}\right)$} & \multirow{2}{*}{$\begin{array}{c}\text { Flesh K } \\
(\%) \\
1986-88\end{array}$} \\
\hline & 1986 & 1987 & 1988 & 1986 & 1987 & 1988 & \\
\hline Ott.3 & $168 \mathrm{ab}$ & $152 \mathrm{~b}$ & $153 \mathrm{a}$ & $233 a$ & $235 \mathrm{~b}$ & $261 a b c$ & $0.61 \mathrm{a}$ \\
\hline M.7 EMLA & $156 \mathrm{abc}$ & $125 \mathrm{c}$ & $143 \mathrm{a}$ & $237 \mathrm{a}$ & $227 \mathrm{bc}$ & $276 \mathrm{a}$ & $0.60 \mathrm{a}$ \\
\hline M.9 EMLA & $151 \mathrm{bc}$ & $143 b c$ & $151 \mathrm{a}$ & $237 \mathrm{a}$ & $231 \mathrm{~b}$ & $249 \mathrm{~cd}$ & $0.62 \mathrm{a}$ \\
\hline M.26 EMLA & $146 \mathrm{c}$ & $130 \mathrm{c}$ & $147 \mathrm{a}$ & $235 \mathrm{a}$ & $234 \mathrm{~b}$ & $268 \mathrm{ab}$ & $0.60 \mathrm{a}$ \\
\hline M.27 EMLA & $139 \mathrm{c}$ & 179 a & $151 \mathrm{a}$ & $233 \mathrm{a}$ & $272 \mathrm{a}$ & $274 \mathrm{a}$ & $0.67 \mathrm{a}$ \\
\hline M.9 & $178 \mathrm{a}$ & $152 \mathrm{~b}$ & $144 \mathrm{a}$ & $229 a$ & $236 \mathrm{~b}$ & $257 \mathrm{bcd}$ & $0.62 \mathrm{a}$ \\
\hline MAC 9 & $169 \mathrm{ab}$ & $173 \mathrm{a}$ & $154 \mathrm{a}$ & $237 \mathrm{a}$ & $261 \mathrm{a}$ & $252 \mathrm{bcd}$ & $0.63 \mathrm{a}$ \\
\hline OAR 1 & $151 \mathrm{bc}$ & $117 \mathrm{c}$ & $122 \mathrm{~b}$ & $227 \mathrm{a}$ & $212 \mathrm{c}$ & $242 \mathrm{~d}$ & $0.65 \mathrm{a}$ \\
\hline
\end{tabular}

${ }^{2}$ Mean separation within columns by Duncan's new multiple range test, $P=0.05$.

y Data for $\mathrm{Ca}$ and $\mathrm{Mg}$ are means of 70 observations; data for $\mathrm{K}$ are means of 210 observations.

Table 6. Effects of rootstocks on post-storage flesh firmness and incidences of storage disorders in 'Sparkspur Supreme Delicious' apple fruit. ${ }^{z, y}$

\begin{tabular}{|c|c|c|c|c|c|c|c|c|c|}
\hline \multirow[b]{2}{*}{ Rootstock } & \multirow{2}{*}{$\begin{array}{c}\text { Flesh } \\
\text { firmness }(\mathrm{N}) \\
1987-88 \\
\end{array}$} & \multicolumn{2}{|c|}{ Scald (\%) } & \multicolumn{2}{|c|}{$\begin{array}{c}\text { Senescent } \\
\text { breakdown (\%) }\end{array}$} & \multicolumn{2}{|c|}{ Bitter pit (\%) } & \multicolumn{2}{|c|}{ Decay (\%) } \\
\hline & & 1987 & 1988 & 1987 & 1988 & 1987 & 1988 & 1987 & 1988 \\
\hline Ott. 3 & $55.2 \mathrm{ab}$ & $12 \mathrm{bc}$ & $21 \mathrm{bc}$ & $16 \mathrm{bc}$ & $32 \mathrm{bc}$ & $3 b c$ & $3 a$ & $17 \mathrm{bc}$ & $45 \mathrm{abc}$ \\
\hline M.7 EMLA & $56.0 \mathrm{a}$ & $10 \mathrm{bc}$ & $32 \mathrm{~b}$ & $28 \mathrm{~b}$ & $13 \mathrm{~cd}$ & $9 \mathrm{a}$ & $4 \mathrm{a}$ & $27 \mathrm{~b}$ & $27 \mathrm{~cd}$ \\
\hline M.9 EMLA & $53.6 \mathrm{c}$ & $22 \mathrm{ab}$ & $19 \mathrm{bc}$ & $21 \mathrm{bc}$ & $23 \mathrm{bcd}$ & $5 \mathrm{~b}$ & 3 & $15 b c$ & $36 \mathrm{bc}$ \\
\hline M.26 EMLA & $53.7 \mathrm{bc}$ & $11 \mathrm{bc}$ & $17 \mathrm{c}$ & $22 \mathrm{bc}$ & $22 \mathrm{bcd}$ & $3 \mathrm{bc}$ & $3 a$ & $19 \mathrm{bc}$ & $38 \mathrm{bc}$ \\
\hline M.27 EMLA & $\ldots$ & $\ldots$ & $54 a$ & --- & $13 \mathrm{~cd}$ & --- & $0 \mathrm{a}$ & --- & $10 \mathrm{~d}$ \\
\hline M.9 & $54.3 \mathrm{bc}$ & $22 a b$ & $11 \mathrm{c}$ & $12 \mathrm{bc}$ & $51 \mathrm{a}$ & $3 \mathrm{bc}$ & $2 \mathrm{a}$ & $15 \mathrm{bc}$ & $64 \mathrm{a}$ \\
\hline MAC 9 & $55.0 \mathrm{abc}$ & $27 \mathrm{a}$ & $8 \mathrm{c}$ & $5 \mathrm{c}$ & $36 \mathrm{~b}$ & $1 \mathrm{c}$ & $3 a$ & $4 \mathrm{c}$ & $55 \mathrm{ab}$ \\
\hline OAR 1 & $54.9 \mathrm{abc}$ & $5 \mathrm{c}$ & $14 \mathrm{c}$ & $68 \mathrm{a}$ & $10 \mathrm{~d}$ & $2 b c$ & $4 \mathrm{a}$ & $63 \mathrm{a}$ & $15 \mathrm{~d}$ \\
\hline
\end{tabular}

${ }^{2}$ Mean separation within columns by Duncan's new multiple range test, $P=0.05$.

'Data for flesh firmness are means of 280 observations; data for storage disorders are means of seven observations.

EMLA, confirming the results of Jackson and Blasco (1975) and Preston et al. (1981). Jackson and Blasco (1985) found that after adjusting for different crop loads, fruit from trees on M.9 were larger than those from trees on M.26, M.7, or MM.106. Preston et al. (1981) found that fruit from trees on M.9A consistently were larger than those from trees on M.27, M.26, or MM.106.

The effects of rootstock on mineral composition are particularly important as they relate to storability. Autio et al. (1986) showed that fruit high in $\mathrm{Ca}$ was less subject to senescent breakdown, bitter pit, and decay. In this study, fruit from trees on MAC 9 consistently had Ca levels in the high category, and those from trees on OAR 1 consistently had Ca levels in the low category. In 1987, this relationship, along with apparent maturity differences, resulted in high levels of senescent breakdown and decay in fruit from trees on OAR 1, with low levels in fruit from trees on MAC 9. In 1988, the effects of Ca were overshadowed by the dramatic maturity differences. The ripest fruit developed the most decay and senescent breakdown. Clearly, rootstock can affect the storability of apples, but these effects appear to be related primarily to rootstock effects on fruit maturity and $\mathrm{Ca}$ concentration.

This study has shown that the effects of rootstock on fruit ripening are not absolute. These effects must be studied for several years, and some of the additional factors that can affect fruit ripening need to be assessed and eliminated.

\section{Literature Cited}

Autio, W. R., W.J. Bramlage, and S.A. Weis. 1986. Predicting poststorage disorders of 'Cox's Orange Pippin' and 'Bramley's Seedling' apples by regression equation. J. Amer. Soc. Hort. Sci. 111:738-742.

Bramlage, W.J. and W.J. Lord. 1967. Watercore and internal breakdown in Delicious apples. Univ. Massachusetts Coop. Ext. Serv. Publ. 11

Cummins, J.N. and R.L. Norton. 1974. Apple rootstock problems and potentials. New York Food \& Life Sci. Bul. 41:1-15.

Drake, S. R., F.E. Larsen, J.K. Fellman, and S.S. Higgins. 1988. Maturity, storage quality, carbohydrate, and mineral content of 'Goldspur' apples as influenced by rootstock. J. Amer. Soc. Hort. Sci. 113:949-952.

Fallahi, E., D.G. Richardson, and M.N. Westwood. 1985a. Influence of rootstock and fertilizers on ethylene in apple fruit during maturation and storage. J. Amer. Soc. Hort. Sci. 110:149-153.

Fallahi, E., D.G. Richardson, and M.N. Westwood. 1985b. Quality of apple fruit from a high density orchard as influenced by rootstock, fertilizers, maturity, and storage. J. Amer. Soc. Hort. Sci. 110:71-74.

Jackson, J.E. and A.B. Blasco. 1975. Effects of rootstock and crop load on fruit size and quality of Cox's Orange Pippin and Worcester Pearrnain. Rpt. E. Mailing Res. Sta., 1974. p. 45.

Larsen, F. E., K.L. Olsen, and R. Fritts, Jr. 1986. Rootstock effects on apple maturity studied. The Goodfruit Grower 37(7):42-47.

Lord, W.J., D.W. Greene, R.A. Damon, Jr., and J.H. Baker. 1985. Effects of stempiece and rootstock combinations on growth, leaf mineral concentrations, yield, and fruit quality of 'Empire' apple trees. J. Amer. Soc. Hort. Sci. 110:422-425. 
Meir, S. and W.J. Bramlage. 1988. Antioxidant activity in 'Cortland' apple peel and susceptibility to superficial scald after storage. J. Amer. Soc. Hort. Sci. 113:412-418.

NC-140. 1987. Growth and production of 'Starkspur Supreme Delicious' on 9 rootstock in the NC-140 cooperative planting. Fruit Var. J. 41:31-39.

Perry, R.L. and D.R. Dilley. 1984. The influence of interstem on ripening indices of 'Empire' apples. Compact Fruit Tree 17:50-54.

Preston, A. P., D.E. Belcher, and B.C. Ley. 1981. Apple rootstock studies: Bramley's Seedling on dwarfing clones. Expt. Hort. 32:1824.
Priest, K.L. and E.C. Lougheed. 1981. Evaluating apple maturity using the starch-iodine test. Ont. Min. Agr. and Food Factsheet 81-025.

Smock, R.M. 1953. Some effects of climate during the growing season on keeping quality of apples. Proc. Amer. Soc. Hort. Sci. 62:272278.

Wallace, T. 1930. Factors influencing the storage qualities of fruit. Proc. First Imperial Hort. Conf., London 3:9-25.

Weis, S. A., W.J. Bramlage, and M. Drake. 1985. Comparison of four sampling methods for predicting poststorage senescent breakdown of 'McIntosh' apple fruit from preharvest mineral composition. J. Amer. Soc. Hort. Sci. 110:710-714. 